\title{
Analisis Budidaya Petani Tambak Terhadap Kondisi Sosial Ekonomi Di Desa Bulu Cindea Kabupaten Pangkajene dan Kepulauan
}

\author{
Sarwana ${ }^{1}$, Yumriani $^{2}$, Lukman |smail ${ }^{3}$ \\ ${ }^{1}$ Pendidikan Sosiologi, Universitas Muhammadiyah Makassar \\ Email: sarwanawhana435@gmail.com \\ ${ }^{2}$ Pendidikan Sosiologi, Universitas Muhammadiyah Makassar \\ Email:yumriani@unismuh.ac.id \\ ${ }^{3}$ Pendidikan Sosiologi, Universitas Muhammadiyah Makassar \\ Email: lukmanismail@unismuh.ac.id
}

\begin{abstract}
The purpose of this study is to find out what causes conflict with in-laws who live at home with inlaws and how to form conflict resolution strategies for in-laws who live at home with in-laws. The research conducted is qualitative research. The research sample uses purposive sampling with 5 informants. Data collection techniques used by researchers are observation, interviews and documentation. Data analysis method used is descriptive method. The results of the research prove that based on observations of these phenomena, it can be seen that the son-in-law who lives at home with in-laws does not feel well-being in his life. Welfare does not just emerge from within the individual, so individuals must learn and get used to achieving that well-being. Most individual problems are driven by feelings of discomfort and cannot control their emotions so that they affect their well-being.
\end{abstract}

Keywords: Analysis, Aquaculture, Social, Economic

Abstrak. Tujuan penelitian ini adalah untuk mengetahui Untuk mengetahui implikasi Budidaya Petani Tambak Terhadap Kondisi Sosial Ekonomi pada masyarakat desa Bulu Cindea Kabupaten Pangkep dan Untuk mengetahui karakteristik petani tambak ikan bandeng di desa bulu cindea kab.pangkep.Penelitian yang dilakukan merupakan penelitian kualitatif. Sampel penelitian mengunakan purposive sampling dengan 5 informan. Teknik pengumpulan data yang lakukan oleh peneliti adalah Observasi, wawancara dan dokumentasi. Metode analisis data yang di gunakan yaitu metode deskriptif. Hasil penelitian membuktikan bahwa Berdasarkan pengamatan terhadap fenomena tersebut dapat dilihat Budidaya petani tambak dapat memberikan dampak ekonomi terhadap masyarakat serta telah menimbulkan adanya penghasilan dan kerugian yang dia dapat usaha. Dengan adanya budidaya tambak, mata pencaharian masyarakat lokal tidak lagi terbatas pada petani dan Karakteristik budidaya petani tambak terdiri dari tingkat usia, tingkat pendidikan dan pengalaman kerja petani tambak

Kata Kunci : Analisis, Budidaya Tambak, Sosial, Ekonomi

\section{PENDAHULUAN}

Budidaya merupakan salah satu pembudidayaan yang dilakukan manusia di Indonesia. Tambak merupakan kolam buatan yang biasanya ada di sekitar pesisir pantai yang di isi air dimanfaatkan sebagai sarana budidaya perairan. Hewan yang dibudidayakan seperti hewan air terutama ikan, udang, serta kerang. Penyebutan tambak ini biasanya di hubungkan dengan air payau atau air laut. Tambak tersebut berisi air tawar biasanya disebut kolam saja atau empang pada umummya proses 
budidaya tambak sangat membantu dalam hal kondisi ekonomi karena membudidayakan bandeng dapat memberikan lapangan pekerjaan, membantu kebutuhan keluarga, pendapatan yang menjanjikan dan peran pemerintah menurut hasil penelitian dari khosiah dan akbar 2018.

Dari persepsi dan partisipasi pada budidaya tambak dapat mempengaruhi dari beberapa faktor seperti strata sosial, pendidikan, pengetahuan terhadap hukum, dan kearifan lokal,begitupun juga perlu adanya dukungan dari seluruh masyarakat. Potensi sumber daya alam yang dimiliki setiap wilayah berbeda-beda, dan mempunyai ciri tersendiri serta kemampuan dalam mengolah potensi sumber daya alam yang ada. Sumber daya alam pada suatu daerah biasanya dapat menentukan mata pencaharian sebagai sumber ekonomi masyarakat untuk memenuhi kebutuhan hidup. Sektor pertanian tambak merupakan sektor yang sangat penting bagi Negara berkembang, seperti halnya Indonesia. Tanah yang subur dan didukung oleh ketersediaan air yang cukup merupakan faktor pendukung pertanian di Indonesia. Pertanian tambak merupakan salah satu mata pencaharian masyarakat Indonesia. Pengelolaan tambak di Indonesia masih terbatas. Keterbatasan modal dan lahan sempit merupakan salah satu kendala dalam pengelolaan.

Kegiatan budidaya sudah dikenal masyarakat sekitar abad ke-14 yang dimulai dengan budidaya secara tradisional di tambak pasang surut berdasarkan manfaat yang diperoleh, menjadikan ikan bandeng sebagai komoditas ekspor yang mampu mendatangkan devisa negara, selain juga berperan penting sebagai penggerak perekonomian rakyat di daerah pesisir. Strategi pembangunan perikanan tetap diarahkan pada peningkatan pendapatan dan kesejahteraan petani pembudidaya dan nelayan. Dalam rangka pencapaian strategi tersebut, maka industri ikan bandeng merupakan suatu rangkaian kegiatan yang saling berinteraksi dalam suatu sistem agribisnis. Melihat hal ini, prospek ikan bandeng cukup cerah.

Budidaya tambak ditujukan untuk mencapai kesejahteraan hidup yang lebih baik bagi pelakunya, maka upaya tersebut tidak bisa dipisahkan dari efisiensi penggunaan sumberd aya dan keterbatasan yang ada pada mereka. Penggunaan faktor input produksi yang tidak efisien bisa menyebabkan rendahnya produktivitas. Selain faktor tersebut juga karena kebiasaan petani bekerja di luar tambak untuk menambah penghasilan. Upaya ini merupakan sesuatu yang baik, akan tetapi dalam jangka panjang seiring dengan perubahan zaman dan keperluan hidup semakin meningkat, keberadaan lahan tambak terdesak oleh pemukiman. Kecenderungan ini menunjukkan bahwa budidaya tambak tidak bisa dijadikan sandaran hidup satu-satunya bagi mereka (Eko Joko Lelono, 2010).

Ikan bandeng selain berfungsi sebagai komoditas ekspor yang mampu mendatangkan devisa negara, juga berperan penting sebagai penggerak perekonomian rakyat di daerah pesisir. Ikan bandeng juga merupakan salah satu jenis ikan yang banyak dikonsumsi oleh masyarakat Indonesia, dikarenakan mempunyai rasa daging yang enak dan harga yang terjangkau. ikan bandeng mempunyai andil yang cukup besar bagi peningkatan gizi masyarakat. Ikan bandeng merupakan komoditas perikanan yang relative mudah dibudidayakan dan teknologinya telah mapan di masyarakat, memiliki nilai pilihan konsumen yang tinggi, serta tahan terhadap perubahan lingkungan yang ekstrim (Andriyanto Septyan, 2013).

Bandeng merupakan salah satu komoditas budidaya dengan peningkatan produksi tahun 2006-2007 sebesar 11,52 \% (DKP 2008). Ikan ini menurut Pasaribu (2004) memiliki keunggulan komparatif, bersifat herbivor, memiliki respon baik terhadap pakan buatan. Pengembangan dapat dilakukan dengan teknik intensif maupun teknik semi intensif. Bandeng tidak hanya dikonsumsi masyarakat lokal, tetapi juga diekspor untuk memenuhi permintaan negara lain. Permintaan bandeng menurut Gumelar (2003) dari tahun ke tahun meningkat untuk tujuan konsumsi, umpan tuna cakalang, maupun ekspor. Permintaan ini berdasarkan Sistem Informasi Terpadu Pengembangan Usaha Kecil (SIPUK) (2003) tahun 1990-2003 rata-rata meningkat 6,33\% per tahun, tetapi produksi hanya meningkat dengan 3,82\%. Permintaan pasar berdasarkan Swastha dan Irawan (2005) ditentukan oleh beberapa faktor seperti harga produk, harga produk lain, penghasilan pembeli dan selera pembelim (Setiawan Rudini Asep, 2009). 
Kepala Bidang Budidaya Ikan Dinas Kelautan dan Perikanan Kabupaten Pangkep, M Sabrun mengatakan, penyebab utamanya adalah sumber makanan bandeng dan kondisi tanah tambak. Memang beda rasa dagingnya, itu karena dilihat dari faktor makanan yang mereka makan, bandeng itu herbivor pemakan tanaman jenis pitoplankton, Alga yang tumbuh di sekitar tambak tidak menyebabkan cita rasa bandeng terganggu. Justru itulah karena alga, lumut-lumut sekitar area tambak yang sehat untuk pertumbuhan ikan Bandeng katanya. Selain faktor makanan, jenis tanah tambak dan cara memberi makan juga memengaruhi cita rasa daging bandeng. Tanah mempengaruhi pertumbuhan plankton dan tekstur tanah tersebut akan menghasilkan makanan alami di sekitar tambak. Soal cara penambak memberi bandeng makanan, yakni tradisional plus dan tidak diberi makan setiap hari. Tapi ikan bandeng tersebut memakan plankton-plankton, alga, lumutlumut dan lekat-lekat yang hidup di sekitar area tambak.

Desa Bulu Cindea mengandalkan bidang pertanian dan Empang serta nelayan sebagai tulang punggung ekonomi desa, terdiri dari lahan persawahan, tanah empang, selain itu juga banyak warga yang berpotensi sebagai nelayan. Pengelolaan Potensi Sumber Daya Alam seperti pertanian, empang serta peternakan hanya dilakukan dalam skala terbatas atau dalam skala rumah tangga. Tidak ada investasi besar dalam pengelolaan tersebut sehingga produktivitasnya juga terbatas. Potensi perikanan juga sebenarnya dapat dikembangkan sehubung tersedianya media budidaya ikan berupa Bandeng, Mujair, Udang Windu dan Paname tetapi potensi tersebut belum dikelolah secara Propesional.

Tanah mempengaruhi pertumbuhan plankton dan tekstur tanah tersebut akan menghasilkan makanan alami di sekitar tambak. Soal cara penambak memberi bandeng makanan, yakni tradisional plus dan tidak diberi makan setiap hari. Tapi ikan bandeng tersebut memakan plankton-plankton, alga, lumut-lumut dan lekat-lekat yang hidup di sekitar area tambak.

Adapun yang melatarbelakangi sehingga peneliti mengangkat judul penelitian ini adalah mengenai budidaya petani tambak, eksistensi budidaya petani tambak nampaknya telah menjadi suatu mata pencaharian masyarakat di kabupaten pangkep. Untuk itu adanya budidaya petani tambak tersebut yang menjadi salah satu ekonomi masyarakat sehingga memberi motivasi kepada penulis untuk mencari sebuah kebenaran dengan melakukan penelitian yakni dengan judul "Analisis Budidaya Petani Tambak Terhadap Kondisi Sosial Ekonomi Didesa Bulu Cindea Kabupaten Pangkep".

\section{METODE PENELITIAN}

Jenis penelitian ini adalah kualitatif deskriptif dengan pendekatan fenomenologi yang bertujuan untuk mengetahuan dampak dan karakteristik Petani Tambak Terhadap Kondisi Sosial Ekonomi pada masyarakat desa Bulu Cindea Kabupaten Pangkep Sampel penelitian mengunakan purposive sampling dengan 5 informan. Teknik pengumpulan data yang lakukan oleh peneliti adalah Observasi, wawancara dan dokumentasi. Kemudian dianalisis melalui pengumpulan data (data collection) reduksi data (data reduction), model data (data display) penyajian data (display data), penarikan kesimpulan (conclusion) dan menggunakan teknik keabsahan data.

\section{HASIL DAN PEMBAHASAN}

Sesuai dengan hasil penelitian yang menjelaskan tentang Bagaimana impilkasi Budidaya Petani Tambak Terhadap Kondisi Sosial Ekonomi pada masyarakat desa Bulu Cindea olehnya itu peneliti menginterpretasi di dalam pembahasan ini. Petani merupakan bagaimana seseorang bisa melakukan kegiatan pekerjaan utama bertani sebagai mata pencaharian untuk memenuhi kebutuhan diri sendiri dan keluarganya sedangkan tambak merupakan suatu kolam yang di bangun pada daerah pasang surut yang di pergunakan sebagai tempat pemeliharaan seperti ikan, udang dan hewan lain yang hidup di air. tujuan utamanya untuk meningkatkan hasil pendapatan karena dengan adanya hasil pendapatan mampu memenuhi kebutuhan hidup sehari-hari bersama keluarganya.

Keberhasilan budidaya tambak tersebut sangat terpengaruh oleh tersedianya lahan pertambakan yang memiliki persyaratan baik fisik maupun biologi. Dalam keberadaan budidaya 
tambak itu sendiri membawa dampak yang sangat positif dan negative para petani tambak. Para petani tambak berharap bisa mendapatkan keuntungan yang di peroleh agar memberikan kehidupan bagi keluarga. Dampak yang di maksud adalah perubahan yang mengarah pada peningkatan kehidupan sosial ekonomi kekeluarganya. Melalui hasil observasi dapat di ketahui bahwa petani tambak di desa bulu cindea ini rata - rata lebih dari 10 tahun lamanya berusaha membuka lahan tambak. Kehidupan sosial dan ekonomi petani tambak di inginkan pada usaha memperoleh keuntungan dari hasil panen ikan bandeng dan yang lainnya dari tambak mereka.

Keberadaan budidaya tambak itu sendiri membawa dampak yang sangat positif bagi para petani tambak. mengatasi dampak itu perlu ada solusi agar para petani tambak tersebut tidak mengalami kerugian. Sosial ekonomi merupakan kedudukan seseorang dalam kelompok sosial ekonomi sebagai pengelompokkan orang berdasarkan kesamaan karakteristik pelajaran dan pendidikan ekonomi. Dampak itu terbagi menjadi 2 yaitu dampak positif dan negatif. Kegiatan budidaya tambak (ikan bandeng) akan menimbulkan dampak terhadap masyarakat sekitar lokasi tambak.

Salah satu dampak yang paling terasa adalah adanya dampak ekonomi. Implikasi budidaya petani tambak suatu perubahan yang mendatangkan pada pengaruh atau akibat. Dalam setiap keputusan yang diambil oleh seseorang atau biasanya mempunyai dampak tersendiri baik itu dampak positif maupun negatif. Perairan yang luas dan melimpah juga dapat dimanfaatkan sebesarbesarnya untuk pemenuhan kebutuhan manusia secara ekonomi. Begitupun dengan potensi tambak yang merupakan bagian dari pengembagan wilayah perairan, baik di laut maupun di darat diharapkan dapat dimanfaatkan oleh para petani tambak. Pemanfaatkan area wilayah yang dijadikan lokasi budidaya tambak memiliki nilai ekonomis yang cukup tinggi. Agar dengan adanya pengelolaan sumber daya perairan, perikanan yang baik akan meningkatkan pendapatan petani tambak.

Dampak positif itu perubahan yang menjadi hasil lebih baik dalam melakukan sesuatu sedangkan dampak negatifnya pengaruh yang mendatangkan akibat negatif atau biasa di simpulkan pengaruh buruk yang lebih besar yang bisa merugikan manusia. Kegiatan budidaya tambak (ikan bandeng) akan menimbulkan dampak terhadap masyarakat sekitar lokasi tambak. Salah satu dampak yang paling terasa adalah adanya dampak ekonomiDampak ekonomi yang muncul dapat bersifat positif dan negatif. dampak positif terbagi menjadi 2 yaitu dampak positif langsung dan tidak langsung, dampak positif langsung seperti munculnya lapangan kelja baru bagi masyarakat sekitar, dan mampu untuk mendapatkan barang dan jasa demi memenuhi kebutuhan tambak mereka seperti: pakan, obat serta pupuk untuk ikan bandeng, dan benih ikan bandeng di sekitar lokasi tambak. Hal yang demikian akan membuka kesempatan bagi masyarakat lokal untuk meningkatkan taraf perekonomian keluarga.

Selain dampak positif langsung yang muncul, ada dampak lain yang akan timbul seperti dampak tidak langsung. Dampak tidak langsung berupa aktivitas ekonomi lokal dari suatu pembelanj aan unit usaha penerima dampak langsung dan dampak lanjutan dapat diartikan sebagai aktivitas ekonomi lokal lanjutan dari tambahan tenaga kerja. Dampak ekonomi yang ditimbulkan budidaya ikan bandeng pada dasarnya dilihat dari keseluruhan pengeluaran petani tambak untuk pembelian pakan, benih dan obat untuk ikan serta pengeluaran lainnya sedangkan dampak negatifnya dari budidaya petani tambak yaitu kegiatan budidaya tambak bandeng secara ekologi dan sosial ekonomi yang tidaj sedikit jika tidak dikelola dengan baik.

Dampak-dampak negatif tersebut, di antaranya: degradasi dan penurunan luas Kawasan mangrove dan pencemaran perairan akibat peningkatan beban nutrient ke dalam perairan yang dapat menyebabkan budidaya tambak perpotensi menjadi masalah sosial ekonomi, seperti konflik di pesisir akibat pemanfaatan ruang yang kurang tepat bahkan konflik antar petambak. Konflik tersebut dapat dipicu atas pemanfaatan dan penggunaan sumber air, dampak pembuangan limbah dan lain-lain.

Adanya dampak bisa mendatangkan adanya keuntungan dan kerugian terhadap petani karena membudidayakan petani tambak bisa menghasilkan yang namanya penghasilan ekonomi agar petani tambak bisa memenuhi kebutuhan hidupnya dan keluarga. Keberadaan budidaya tambak itu sendiri 
membawa dampak yang sangat positif bagi para petani tambak. mengatasi dampak itu perlu ada solusi agar para petani tambak tersebut tidak mengalami kerugian.

Sebagai petani tambak perlu adanya pemahaman terkait pola makan ikan disebut bisa membantu meneltralisirkan kelebihan pemberian pakan. Selain itu, menyarankan agar pemberian pakan dilakukan secara bertahap dan tidak sekaligus ditabur. Dengan demikian, pembudidaya bisa berhenti ketika sudah tidak lagi menyabar makanan bagi terapung di air

Kerusakan ekosistem mangrove di sebabkan oleh pembukaan lahan tambak (udang maupun bandeng) yang dipicu oleh harga komoditas yang cukup menjanjikan (tinggi) dan kemudahan bagi masyarakat untuk memperoleh lahan di wilayah mangrove untuk kegiatan pertambakan. Kegiatan budidaya yang dilakukan dengan membuka hutan mangrove akan berpengaruh pada berkurangnya populasi ikan disekitar perairan tersebut. Karena hutan mangrove merupakan ekosistem yang penting baik bagi makanan dan tempat mencari makan.

Karakteristik sosial ekonomi menjadi salah satu faktor yang menjadi pertimbangan dalam menetukan model, dan arah pengembangan tata ruang 6 . Keterlibatan masyarakat dalam sebuah proses pengembangan wilayah diharapkan dapat memberikan berbagai masukan yang penting, oleh sebab itu karakteristik sosial ekonomi responden menjadi penting untuk diketahui Karakteristik sosial ekonomi petani tambak di Desa bulu cindea yang diperoleh .Karakteristik tersebut dapat dilihat berdasarkan kriteria tertentu, seperti dijelaskan dibawah ini.

\section{Tingkat Usia}

Usia petani tambak dibedakan atas tiga kategori orang dewasa menurut yaitu usia dewasa awal (18 - 30 tahun), dewasa pertengahan (31-50 tahun), serta dewasa tua ( $>50$ tahun). Berdasarkan hasil penelitian, tingkat usia cukup bervariasi dengan sebaran usia antara 29 tahun sampai 60 tahun. Sebaran usia sebagian besar petani tambak mulai bekerja sebagai petani tambak antara umur dewasa awal $31-50 \mathrm{Hal}$ ini dikarenakan, mayoritas petani tambak menjadikan budidaya ikan bandeng ini sebagai mata pencaharian utama, sehingga banyak dari mereka yang melakukan kegiatan ini pada usia produktif mereka, dan beberapa petani tambak yang lain masih terus melakukan kegiatan ini meski sudah cukup berumur.

Petani tambak di desa bulu cindea memiliki usia yang beragam bahwasanya sebagia besar memiliki usia yang masih produktif, hal tersebut sangat baik untuk kegiatan pengelolaan usaha budidaya tambak maupun memenuhi kebutuhan hidup anggota keluarga karena dengan usia yang produktif bisa melakukan usaha dalam budidaya tambak sehingga tanggungan keluarga terpenuhi. Hal ini dikarenakan mayoritas petani tambak menjadikan sebagai mata pencaharian utama,sehingga banyak dari mereka melakukan kegiatan ini.

Petani tambak di desa bulu cindea memiliki pengalaman budidaya tambak yang sangat beragam, berdasarkan data tersebut tingkat pengalaman budidaya tambak para petani tambak di desa bulu cindea tersebut memadai atau baik untuk usaha budidaya tambak, akan tetapi walaupun tingkat pendidikan formal yang dimiliki petani tambak sebagian besar tamatan SD/Sederajat tidak besar berpengaruh terhadap kegiatan usaha budidaya tambak karena pengelolaan usaha budidaya tambak tersebut tidak hanya pendidikan formal yang dibutuhkan pengalaman atau keterampilan pengelolaan usaha budidaya sangat dibutuhkan juga sehingga petani tambak yang memiliki pendidikan formal.

\section{Tingkat Pendidikan}

Pendidikan merupakan salah satu aspek yang sangat penting dalam kehidupan kerena pendidikan memberikan beribu macam informan pengetahuan dan keterampilan yang belum tentu kita dapatkan berdasarkan pengalaman empiris. Menguasai ilmu pengetahuan dan keterampilan berarti memiliki bekal dalam menghaapi segala tantangan dalam kehiupan. Oleh karena itu sudah selayaknya bagi setiap masyarakat untuk mengenyam dunia pendidikan. Hakikat pendidikan adalah untuk mengembangkan, meningkatkan mutu kehidupan dan martabat manusia baik individu maupun sosial. Pendidikan berfungsi sebagai sarana pemberdayaan individu dan masyarakat guna 
menyonsong masyarakat yang lebih baik. Tingkat pendidikan yang dimaksud dalam penelitian ini adalah tingkat pendidikan formal yang pernah ditempuh. Berdasarkan hasil wawancara dari petani tambak tingkat pendidikan dilokasi penelitian cukup bervariasi yaitu tidak sekolah, SD, SMP, dan SMA. Berikut ini akan disajikan keadaan pendidikan sampel peneliti pada petani sawah menjadi petani tambak di Desa Bulu Cindea. petani tambak di desa bulu cindea memiliki usia yang beragam bahwasanya sebagia besar memiliki usia yang masih produktif, hal tersebut sangat baik untuk kegiatan pengelolaan usaha budidaya tambak maupun memenuhi kebutuhan hidup anggota keluarga karena dengan usia yang produktif bisa melakukan usaha dalam budidaya tambak sehingga tanggungan keluarga terpenuhi.

tingkat pendidikan yang paling banyak mulai bekerja sebagai petani tambak tingkat SMA karena pekerjaan sekarang sulit untuk di temukan pada tingkat SMA jadi dia harus bekeja petani karena melakukan pekerjaan tambak bisa juga menghasilkan ekonomi. Tingkat pendidikan pada petani tambak salah satu yang penting di lihat dari pendidikn formal yang pernah ditempuh oleh petani dari sekolah dasar sampai ke perguruan tinggi. Dalam pendidikan pada tambak mampu menjelaskan daya piker petani bagaimana mengelola dan meningkatkan hasil produksinya.

Tingkat pendidikan petani tambak di sebagian besar tamatan SD/Sederajat, meskipun demikian tingkat pendidikan petani tambak bukan penghalang atau salah satunya indikator bagi petani tambak untuk melakukan kegiatan yang dapat menunjang aataupun meningkatkan taraf kehidupan mereka. Jumlah petani tambak berdasarkan responden sebagian besar usia produktif yaitu 36-60 tahun ini tentu sangat baik karena untuk melakukan kegiatan usaha budidaya tambak bawasannya dengan usia produktif petani tambak akan melakukan kegiatan pengelolaan usaha budidaya tambak tersebut secara maksimal. Tingkat pendidikan formal dan jumlah tanggungan, sedangkan karakteristik ekonomi meliputi : tingkat pendapatan, pekerjaan tambahan, dan pemenuhan kebutuhan pokok. Berdasarkan pendekatan tersebut yang dimaksud sosial ekonomi dalam penelitian ini adalah tingkat pendidikan.

Potensi sumber daya alam di daerah pesisir patai utara pulau jawa memiliki potensi yang baik untuk budidaya peikanan maupun tambak. Kecamatan bungoro termasuk wilayah yang berada di daerah pesisir pantai utara pulau jawa. Dimana di daerah ini banyak dijumpai area tambak-tambak baik tambak udang, tambak garam maupun tambak bandeng. Kegitan pertambakan tersebut merupakan salah satu bentuk usaha kegiatan masyarakat di Kecamatan Bungoro. Di Kecamatan Bungoro sendiri terdapat dua desa yang memiliki potensi budidaya tambak udang besar sedangkan daerah pesisir lainya dimanfaatkan sebagai tambak garam dan tambak bandeng ataupun dibiarkan begitu saja sebagai lahan kosong. Dua desa yang memiliki potensi tersebut adalah desa dan desa bulu cindea. Luas wilayah yang digunakan untuk area budidaya tambak udang di desa Sluke mencapai $10 \mathrm{Ha}$, sedangkan untuk desa Trahan sendiri kurang lebih $4 \mathrm{Ha}$ meskipun dulu sebelum terjadi pembangunan PLTU desa bulu cindea juga memiliki luas area tambak udang yang cukup besar. Perubahan luas area tambak dikarenakan adanya perubahan penggunan lahan. Pelaku budidaya tambak udang di Kecamatan bungoro terdiri dari dua jenis yaitu orang yang memiliki lahan tambak udang serta orang yang menyewa lahan untuk dijadikan area tambak udang.

Petani tambak diartikan sebagai orang yang aktif melakukan pekerjaan mengelola tambak dalam memperoleh pendapatannya. Petani tambak ini tinggal di desa pesisir atau berdekatan dengan lokasi tambak dan mata pencaharian utamanya berasal dari mengelola tambak. Bagi petani tambak, kebutuhan fisik minimum atau kebutuhan konsumsi keluarga sangat ditentukan oleh pendapatan yang diteri-manya. Untuk memperoleh pendapatan yang tinggi maka petani tambak harus bisa meningkatkan hasil budidaya tambak. Selain itu petani tambak juga harus bisa menjaga dan memperbaiki kualitas budidaya tambak. Untuk menjaga dan memperbaiki kualitas budidaya tambak, diperlukan ada-nya peralatan (teknologi) yang memadai serta tenaga kerja yang berpengalaman (Jummaini, 2008).

Dari hasil observasi yang saya lihat di desa bulu cindea kabupaten pangkep dalam dampak budidaya tambak terhadap kondisi sosial ekonomi yang dulu dan sekarang sangat berbeda karena 
adanya petani tambak bisa menghasilkan ekonomi yang cukup memuaskan bagi masyarakat yang ada bulu cindea bahkan hamper setiap panen ikan.

Petani tambak di desa bulu cindea memiliki pengalaman budidaya tambak yang sangat beragam, brdasarkan data tersebut tingkat pengalaman budidaya tambak para petani tambak di desa bulu cindea tersebut memadai atau baik untuk usaha budidaya tambak, akan tetapi walaupun tingkat pendidikan formal yang dimiliki petani tambak sebagian besar tamatan SD/Sederajat tidak besar berpengaruh terhadap kegiatan usaha budidaya tambak karena pengelolaan usaha budidaya tambak tersebut tidak hanya pendidikan formal yang dibutuhkan pengalaman atau keterampilan pengelolaan usaha budidaya sangat dibutuhkan juga sehingga petani tambak yang memiliki pendidikan formal.

Tingkat pendidikan petani tambak di sebagian besar tamatan SD/Sederajat, meskipun demikian tingkat pendidikan petani tambak bukan penghalang atau salah satunya indikator bagi petani tambak untuk melakukan kegiatan yang dapat menunjang aataupun meningkatkan taraf kehidupan mereka. Jumlah petani tambak berdasarkan responden sebagian besar usia produktif yaitu 36-60 tahun ini tentu sangat baik karena untuk melakukan kegiatan usaha budidaya tambak bawasannya dengan usia produktif petani tambak akan melakukan kegiatan pengelolaan usaha budidaya tambak tersebut secara maksimal. Tingkat pendidikan formal dan jumlah tanggungan, sedangkan karakteristik ekonomi meliputi : tingkat pendapatan, pekerjaan tambahan, dan pemenuhan kebutuhan pokok. Berdasarkan pendekatan tersebut yang dimaksud sosial ekonomi dalam penelitian ini adalah tingkat pendidikan..

Tambak merupakan tempat yang basah tetapi biasanya di pakai untuk memelihara berbagai ikan seperti ikan bandeng, udang, ikan nila atau ikan mujair. Atau bisa diartikan sebagai kolam yang dibangun untuk membudidayakan ikan, udang dan hewan air lainya yang hidup di air. Jadi dapat disimpulkan tentang arti dari Petani tambak adalah petani udang, ikan atau sejenis hewan air, yang dimana orang tersebut memperoleh mata pencaharian pokok dengan melakukan kegiatan di bidang budidaya ikan di tambak.

Keadaan sosial ekonomi setiap daerah berbeda tergantung sumber daya alam dan sumber daya manusianya. Sebuah para ahli menyatakan bahwa, karakteristik sosial ekonomi itu adalah sifat-sifat khusus yang dimiliki suatu petani yang berkaitan dengan teori solidaritas sosial ekonominya. Karakteristik sosial meliputi : tingkat usia, tingkat pendidikan , tingkat pendapatan dan status pekarjaan petani.

\section{Pengalaman Sebagai Petani Tambak}

Dengan pengalaman sebagai petani tambak merupakan faktor yang sangat dalam seberhasilan di dapatkan, semakin banyak pengalaman didapatkan maka petani tambak tersebut memiliki kemampuan yang tinggi dalam mengelolahnya. pengalaman memberikan kemampuan dan lebih mudah dalam menjalankan budidaya tambak karena dari pengalaman itu banyak yang dia ketahui tentang proses budidaya tambak.

Pengalaman memberikan kemampuan dan lebih mudah dalam menjalankan budidaya tambak karena dari pengalaman itu banyak yang dia ketahui tentang proses budidaya tambak. Semua petani tambak suatu pengalaman yang bisa jalani sebagai mata pencaharian agar bisa menguntungkan kehidupannya dalam usahanya budidaya. Jika petani tambak menjadikan sebagai pengalaman maka waktu yang diberikanpun bisa berjalan, hal ini bisa berpengaruh terhadap proses budidaya tersebut sebagai focus atau tidak berimplikasi terhadap hasil produksi serta pendapatan yang diterima oleh petani.

Budidaya petani tambak menciptakan adanya kondisi masyarakat tradisional .kerjasama dalam suatu hubungan antara individu ataupun kelompok rasa saling percaya untuk mencapai tujuan yang dia inginkan. Begitu pula dengan adanya yang ditandai dengan hubungan erat dengan kelompok petani tambak. 


\section{KESIMPULAN}

1. Budidaya petani tambak dapat memberikan dampak ekonomi terhadap masyarakat serta telah menimbulkan adanya penghasilan dan kerugian yang dia dapat usaha. Dengan adanya budidaya tambak, mata pencaharian masyarakat lokal tidak lagi terbatas pada petani.

2. Karakteristik budidaya petani tambak terdiri dari tingkat usia, tingkat pendidikan dan pengalaman kerja petani tambak dan Budidaya tambak telah memberikan dampak nyata secara ekonomi pada masyarakat lokal baik secara langsung, tidak langsung dan lanjutan, meskipun memiliki nilai relatif, dan juga menunjukan bahwa proses budidaya tambak dalam penelitian ini belum mencapai kondisi optimal

\section{DAFTAR PUSTAKA}

Arikunto, Suharsimi, 2002. Prosedur Penelitian Suatu Pendekatan Praktek. Jakarta. PT. Rineka Cipta.

Asep Rudini Setiawan(2009) Studi Pelelangan Bandeng Di Kabupaten Pangkajene dan Kepulauan, Provinsi Sulawesi Selatan,skripsi Manajemen Bisnis dan Ekonomi Perikanan dan Kelautan No. C4410302

Emzir. 2010. Metodologi Penelitian Kualitatif: Analisa Data. Jakarta: Raja Grafindo.

Eko joko lelono (2010) Penguatan Kinerja Budidaya Ikan Bandeng Dalam Rangka Pencapaian Ketahanan Pangan, jurnal ekonomi pembangunan, 11(2)202-216

Nursalam, Suardi, Syarifuddin (2016) Teori Sosiologi Klasik, Modern, Postmodern, Saintifik, Hermaneutik, Kritis Evaluative, Integratif, Yogyakarta : gembira UH.V N.45, Umbulharjo

Nazir, Moh. 2005. Metode Penelitian. Jakarta: Ghalia Indonesia.

Moleong, Lexy J. (2001). Metodologi Penelitian Kualitatif. Bandung: Remaja Rosdakarya.

Miles, M.B \& Huberman A.M. 1984, Analisis Data Kualitatif. Terjemahan oleh Tjetjep Rohendi Rohidi. 1992. Jakarta : Penerbit Universitas Indonesia.

Septyan andriyanto(2003) Kondisi Terkini Budidaya Tambak Ikan Bandeng Pati, jawa tengah. Media akuakultur, 8(2) 139-144

Sugiyono. 2011. Metode Penelitian Kuantitatif, Kualitatif dan R\&D. Bandung: Afabeta

Khosiah dan akbar(2010), kajian sosial ekonomi masyarakat pesisir dalam membudidayakan bandeng di desa rupe kecamatan langgudu kabupaten bima JISIP.2(1) 2598-9944

Yuyun maryuningsuh(2004) analisis persepsi dan partisipasi masyarakat pesisir pada pebgelolahan dan pemanfaatan hasil laut kesejahteraan keluarga(studi kasus pada nelayan dan pembudidayaan ikan di desa karangreja kec. Suranenggala kab. Cirebon) scientiance educatia

HTTP://bulucindeadesawisata.blogspot.com/2017/09/profil-desa-bulu-cindea-kec-bungoro-kab.html http://pengertianahli.id/2014/08/pengertian-analisis-apa-itu-analisis.html

$J$ David Sura Wijaya (2016) Profil Keadaan Sosial Ekonomi Keluarga Petani Tambak Di Desa Margasari Kecamatan Labuhan Maringggai Kabupaten Lampung Timur Tahun 2016, skripsi, Fakultas Keguruan Dan IImu Pendidikan Universitas Lampung Bandar Lampung 